Plant Tissue Cult. \& Biotech. 23(1): 21-29, 2013 (June)

$\overline{\text { PTC\&B }}$

\title{
A Novel Method for Efficient Micropropagation of Radermachera xylocarpa (Roxb.) K. Schum., a Rare Medicinally Important Forest Species
}

\section{Manjary Sathe, Megha Vibhute, Monica Jain ${ }^{1}$ and Pankaj Srivastav}

Forest Research and Extension Circle, Asharam Bapu Chouraha, Indore, M.P. 452001, India

Key words: Radermachera xylocarpa, Micropropagation, Rare forest species

\begin{abstract}
Radermachera xylocarpa (Roxb.) K. Schum. is a rare indigenous forest tree species which is utilized for its wood and medicinal properties. Due to its overexploitation and specific habitat requirements the species is restricted to limited areas. In vitro mass propagation of tree species faces various challenges and no such efforts have yet been taken in propagation of this useful plant using these methods. In order to overcome the hurdles and understanding an urgent need of its conservation and mass propagation present authors attempt to develop a simple effective tissue culture protocol for regeneration of $R$. xylocarpa. Nodal explants were cultured on MS supplemented with various concentrations of cytokinins and auxins. Among different cytokinins, maximum bud induction and proliferation was obtained in media supplemented with $\mathrm{Kn}$ along with IBA and for effective root induction which is tough to obtain in tree species, $100 \%$ rooting was achieved in cultures with increasing concentrations of IBA. Field survival is a major challenge with regenerated plants of forest tree species. We report here for the first time $100 \%$ survival of plants in soil by carefully standardizing the period of hardening and acclimatization procedures. A novel and effective in vitro regeneration protocol of $R$. xylocarpa has been successfully standardized which can be adopted for large scale propagation, reforestation and conservation of rare Radermachera xylocarpa of medicinal importance.
\end{abstract}

${ }^{1}$ Author for correspondence: <science2002@rediffmail.com>. Department of Life Sciences, Maharaja Ranjit Singh College of Professional Sciences, Hemkunt Campus, Khandwa road, Indore M.P. 452001, India. 


\section{Introduction}

Radermachera xylocarpa is a rare deciduous tree species belongs to Bignoniaceae. The tree species is exploited for its wood and medicinal value. It is useful for skin diseases, wound healing and on snake bite (Singh et al. 2012, Misra 2004). Oil from the wood is used in cutaneous disease. The leaves of Radermachera are good source of dinatine-7-glucuronide, roots yield o-acety-loleanic acid (Desai et al. 1977), stismasterol and radermachol (Joshi et al. 1984) and stem bark yield antimicrobial lapachol (Shetgiri et al. 2001). In spite of its continuous exploitation for its wood and its medicinal uses, this species has not yet been worked out for its conservation and propagation.

Micropropagation offers a rapid means of producing large quantity of clonal planting stocks and propagation of tree species that are difficult to establish conventionally (Bonga 1987). Numerous recalcitrant forest trees of economic value are still difficult to establish in vitro (Anna et al. 2010) mainly due to reduced or absence of morphogenetic ability (Bonga 2010), high level of contamination (Drew 1988) and poor rooting of the regenerated shoots. However, induction of cellular differentiation in vitro also depend on genetic totipotency, culture medium formulation, and incubation conditions (Gasper et al. 1987). There are no documented studies on the micropropagation of $R$. xylocarpa or any member of this genus. This paper describes for the first time a successful protocol on in vitro regeneration and field survival of Radermachera xylocarpa from nodal cuttings.

\section{Material and Methods}

Nodal cuttings of $R$. xylocarpa were collected from healthy stock plants maintained at Demo nursery, Forest Research and Extension Circle, Indore, M.P., India. They were washed with $5 \%(\mathrm{v} / \mathrm{v})$ Tween-20 and subsequently surface sterilized with $0.1 \% \mathrm{HgCl}_{2}$ for $5 \mathrm{~min}$ followed by rinse with $70 \%$ ethanol for 1 min and then washed thoroughly with sterilized double distilled water (three times) to remove the traces of chemicals.

The nodal explants were aseptically placed in test tube $(25 \mathrm{~mm} \times 150 \mathrm{~mm})$ containing MS supplemented with different concentrations of growth regulators and sucrose (3\%). The $\mathrm{pH}$ of the medium was adjusted to 5.8 using $0.1 \mathrm{~N} \mathrm{HCl}$ or $0.1 \mathrm{~N} \mathrm{NaOH}$ before autoclaving and solidified with $0.8 \%$ agar. Molten medium $(20 \mathrm{ml})$ was dispensed in each culture tube. The medium was sterilized at 1.05 $\mathrm{Kg} / \mathrm{cm}^{2}$ for $15 \mathrm{~min}$. All cultures were incubated in $16 \mathrm{hrs}$ light/ $8 \mathrm{hrs}$ dark photoperiod under light intensity of $50 \mu \mathrm{E} / \mathrm{m}^{2} / \mathrm{s}$ at $25 \pm 2{ }^{\circ} \mathrm{C}$ with $80 \%$ relative humidity. 
MS for shoot induction was supplemented with viz. BAP $0.5-3.0 \mathrm{mg} / \mathrm{l}, \mathrm{Kn}$ 0.5 - $3.0 \mathrm{mg} / \mathrm{l}$, IBA $0.1-0.2 \mathrm{mg} / \mathrm{l}$ (Table 1). Observations were taken after every 15 days. After 20 days of culture the shoots were subcultured in the similar medium combinations for multiplication.

Proliferated shoots measuring about $3-4 \mathrm{~cm}$ in length were isolated and transferred to MS supplemented with (3\%) sucrose. The MS was fortified with IAA, IBA and NAA in concentrations ranging from $1.0-10 \mathrm{mg} / \mathrm{l}$ for rooting.

The plantlets of $4-5 \mathrm{~cm}$ in length were removed from rooting medium and washed gently to remove agar using distilled water. They were transferred to soil and vermiculite $(1: 1)$ mixture covered initially with a transparent disposable plastic tumbler (having holes) and kept in the culture room for two weeks. The plants were watered once a day. After two weeks, the cover was removed and the plants were further kept for one week in the culture room. Plants were then transferred to root trainers containing soil + sand + vermiculite $(1: 1: 1)$ mixture and placed in a greenhouse for one week. After this the plants were subjected to field trials for completing their acclimation.

Each treatment contained 20 explants in three repeated experiments. Data were recorded for percentage of aseptic explants, explants initiating axillary shoots, shoot length, number of rooted shoots and survival of plants in soil.

\section{Results and Discussion}

Approximately $85 \%$ of the nodal cuttings remained aseptic. No leaching was observed from the explants during the treatment or after the incubation. On increasing the duration of the mercuric chloride treatment followed by alcohol treatment the explants turned brown and unhealthy. Hence, the surface sterilization procedure was found durable for the nodal explants of R. xylocarpa.

One week after incubation in shooting medium, the axillary buds started to burst. At least, two axillary shoots developed per node (Fig. 1a). Within two weeks of culture the axillary shoots grew and developed under the provided culture conditions. Kn and BAP were tested in isolation for shoot induction but none of them influenced healthy shoot induction. The shoots developed in Kn supplemented cultures were thin, light green and not so healthy. A large amount of callusing was observed at the basal portion of the explants cultured in supplemented with BAP medium (data not provided). Hence, lower concentration of IBA $(0.2 \mathrm{mg} / \mathrm{l})$ was tested along with $\mathrm{Kn}$ and BAP for emergence of healthy green shoots from the nodal cuttings. Out of both $\mathrm{Kn}$ and BAP tested along with IBA, Kn effectively induced bud break and healthy green shoots from axillary meristems. BAP in all its tested concentrations with IBA showed high 
amount of callusing with delayed shoot response. No bud breaking was found in media without growth regulators. MS supplemented with different concentrations of $\mathrm{Kn}$ and IBA (Table 1) induced shoots from the axillary meristems but the media supplemented with $3.0 \mathrm{mg} / \mathrm{K} \mathrm{Kn}$ and $0.2 \mathrm{mg} / \mathrm{l} \mathrm{IBA}$ presented the best response in terms of early and maximum number of healthy shoot induction. Within 3 weeks of culture, the axillary meristems elongated and attained $2-3 \mathrm{~cm}$ height.

Table 1. List of various BAP and IBA combinations used for axillary bud proliferation and shoot regeneration.

\begin{tabular}{llllll}
\hline $\begin{array}{l}\text { Sl. } \\
\text { No }\end{array}$ & $\begin{array}{l}\text { Growth } \\
\text { regulator }\end{array}$ & $\begin{array}{l}\text { Conc. } \\
(\mathrm{mg} / \mathrm{l})\end{array}$ & $\begin{array}{l}\text { Sl. } \\
\text { No. }\end{array}$ & $\begin{array}{l}\text { Growth } \\
\text { regulator }\end{array}$ & $\begin{array}{l}\text { Conc. } \\
(\mathrm{mg} / \mathrm{l})\end{array}$ \\
\hline 1 & BAP & 0 & 11 & $\mathrm{Kn}$ & 0 \\
2 & BAP & 0.5 & 12 & $\mathrm{Kn}$ & 0.5 \\
3 & BAP & 1.0 & 13 & $\mathrm{Kn}$ & 1.0 \\
4 & BAP & 2.0 & 14 & $\mathrm{Kn}$ & 2.0 \\
5 & BAP & 3.0 & 15 & $\mathrm{Kn}$ & 3.0 \\
6 & BAP + IBA & $0.5+0.1$ & 16 & $\mathrm{Kn}+\mathrm{IBA}$ & $0.5+0.1$ \\
7 & BAP + IBA & $1.0+0.1$ & 17 & $\mathrm{Kn}+\mathrm{IBA}$ & $1.0+0.1$ \\
8 & BAP + IBA & $2.0+0.2$ & 18 & $\mathrm{Kn}+\mathrm{IBA}$ & $2.0+0.2$ \\
9 & BAP + IBA & $3.0+0.2$ & 19 & $\mathrm{Kn}+\mathrm{IBA}$ & $3.0+0.2$ \\
10 & BAP + IBA & $4.0+0.2$ & 20 & $\mathrm{Kn}+\mathrm{IBA}$ & $4.0+0.2$ \\
\hline
\end{tabular}

Shoot proliferation and multiplication were obtained in the similar medium. A maximum of 8 - 10 shoots emerged from the base of the nodal section within two weeks of culture (Table 2, Fig. 1b). The shoots were separated for further multiplication. Each shoot further proliferated giving out 2 - 3 shoots more in the similar medium combination. The shoots grew up and achieved $4-5 \mathrm{~cm}$ height and possessed 3 - 4 nodes (Fig. 1c). On increasing the concentration of $\mathrm{Kn}$ a large amount of callus formation without significantly affecting the shoot multiplication was observed. Hence, media supplemented with Kn and IBA (3.0 $\mathrm{mg} / \mathrm{l}+0.2 \mathrm{mg} / \mathrm{l}$ ) were found to be the best as it induced healthy shoots without further callusing within two week of culture in the multiplication medium. No further increase in number of shoots was observed on further subcultures. The shoots grew sturdy and remained healthy. Hence, the shoots were transferred to rooting medium after second subculture.

Among IAA, NAA and IBA tested IAA was not effective in inducing the roots. After 2 weeks of culture in the rooting medium with either NAA or IBA $(10 \mathrm{mg} / \mathrm{l})$, roots emerged roots from the base. On comparing the effects of NAA 
and IBA, IBA induced 2 - 3 healthy roots (Fig. 1d) as compared to NAA, which in all concentrations $(1-10 \mathrm{mg} / \mathrm{l})$ promoted weaker roots in bunch with huge amount of callusing at the base (Fig. 1d). The concentrations of IBA ranging from 1 - $9 \mathrm{mg} / \mathrm{l}$, showed delayed and poor response in inducing roots. Whereas maximum number of shoots (94\%) emerged roots in $10 \mathrm{mg} / \mathrm{l}$ IBA which was found to be the most effective concentration for rooting of shoots in R. xylocarpa (Table 3). An additional two weeks on this medium increased the number of roots. The combination of IBA with NAA was also tried but it resulted into brittle roots with large amount of callus formation.

Table 2. Effect of different concentrations of Kn + IBA in MS on shooting.

\begin{tabular}{cccc}
\hline $\begin{array}{c}\text { Sl. } \\
\text { No }\end{array}$ & $\begin{array}{c}\mathrm{Kn}+ \\
\text { IBA }\end{array}$ & $\begin{array}{c}\text { Number of } \\
\text { shoots }\end{array}$ & $\begin{array}{c}\text { Shoot length } \\
(\mathrm{cm})\end{array}$ \\
\hline 1 & 0 & 0 & 0 \\
2 & $0.5+0.1$ & 2 & $0.95 \pm 0.2$ \\
3 & $1.0+0.1$ & 2 & $1.46 \pm 0.4$ \\
4 & $2.0+0.2$ & 5 & $1.88 \pm 0.4$ \\
5 & $3.0+0.2$ & 9 & $4.45 \pm 0.7$ \\
6 & $4.0+0.2$ & 8 & $4.28 \pm 0.2$ \\
\hline
\end{tabular}

Plants attaining height of $2-3 \mathrm{~cm}$ with well developed roots were transferred to soil, sand and vermiculite mixture in culture room where up to $85 \%$ plants survived (Fig. 2a). After three weeks the plantlets were transferred to greenhouse where $70 \%$ of the plants survived. After one week in greenhouse all the surviving plants were transferred to field conditions. Cent per cent survival was observed in the field conditions (Fig. 2b). The survival percentage was greatly affected with the period of hardening steps at each phase. The plants showed a good root system and no morphological abnormalities. This study illustrates for the first time a successful micropropagation system for endangered forest species R. xylocarpa of medicinal importance.

Tissue culture techniques have already revolutionized the mass scale propagation of many crops, however, a lot of its exploitation for forest tree species is not satisfactory. Unlike other plants, tissue culture of trees is beset with very special problems. Some of these include the physiological nature of the material (juvenile and mature phases), general recalcitrant response of the explants, inadequate rooting of the regenerated shoots and the associated problems of poor transfer ratio of established plants into soil (Surendran et al. 2000). 
The present study was carried out to explore the in vitro morphogenic potential of $R$. xylocarpa for conservation and reforestation of rare forest species by micropropagation. Regeneration of $R$. xylocarpa was found to be greatly influenced by $\mathrm{Kn}$ in combination with reduced concentrations of IBA. Existing reports suggest that, when auxins at lower concentrations are combined with cytokinins, they played a critical role in plant regeneration as observed in several

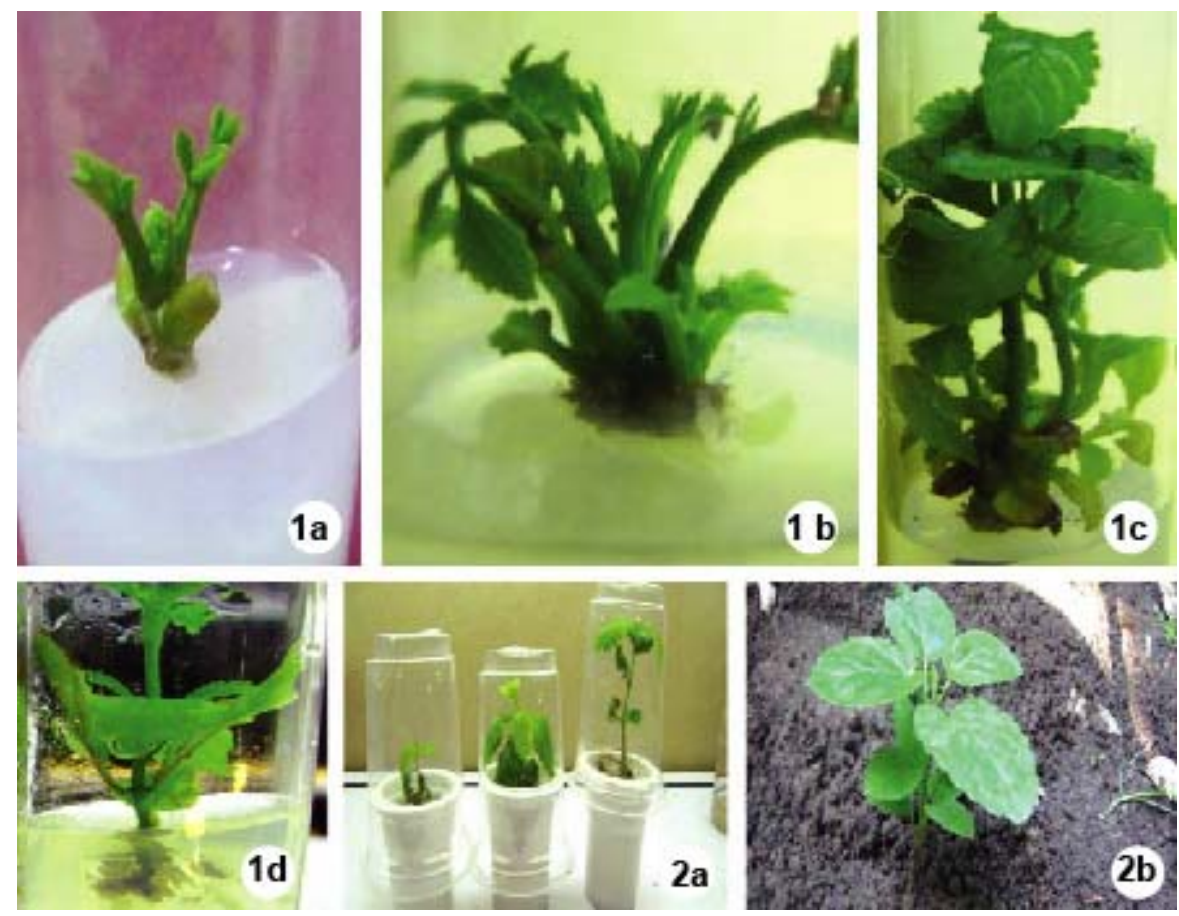

Figs 1 - 2: 1a. Shoot bud induction from nodal cuttings containing axillary buds. 1b. Multiple shoot induction from the axillary meristems of nodal segments. 1c. Proliferation of shoots in the multiplication medium. 1d. Rooting of the shoots in the root induction medium. 2a. Hardening of the in vitro regenerated plants. 2b. Successful survival of regenerated plants in field.

systems like Petasiteshybridus (Wldi et al. 1998), Eucalyptus grandis (Luis et al. 1999), Hybanthusenneaspermus (Prakash et al. 1999), Coleus forskohlii (Sairam et al. 2001), Eleusine indica (Yemets et al. 2003) and Callistemon citrinus (David et al. 2010). IBA in reduced concentrations acted synergistically with $\mathrm{Kn}$ and promoted healthy shoots from the nodal explants. Various reports suggest the influence of different concentrations of plant growth regulators either alone or in combination with other growth regulators on shoot length of the cultured nodal explants (Zaer 1982, Perez-Tornero and Burgos 2000). In the present study maximum shoot length was obtained in cultures grown in MS fortified with 
increased concentrations of $\mathrm{Kn}(3.0 \mathrm{mg} / \mathrm{l})$ along with reduced concentrations of IBA $(0.2 \mathrm{mg} / \mathrm{l})$.

Table 3. Effect of different concentrations of IBA on rooting.

\begin{tabular}{lcccc}
\hline $\begin{array}{l}\text { Sl. } \\
\text { No. }\end{array}$ & Auxin & $\begin{array}{c}\text { Conc. } \\
(\mathrm{mg} / \mathrm{l})\end{array}$ & $\begin{array}{c}\text { Period for } \\
\text { root initiation }\end{array}$ & $\begin{array}{c}\text { Rooting } \\
(\%)\end{array}$ \\
\hline 1 & IBA & 0.5 & - & - \\
2 & $"$ & 1.0 & - & - \\
3 & $"$ & 2.0 & - & - \\
4 & $"$ & 4.0 & $45-50$ days & 20 \\
5 & $"$ & 6.0 & $30-45 "$ & 27 \\
6 & $"$ & 8.0 & $30-45 "$ & 73 \\
7 & $"$ & 10.0 & $15-20 "$ & 94 \\
\hline
\end{tabular}

Root induction from the in vitro derived shoots has been a major constraint for regeneration protocol of forest species. In the present study higher concentrations of IBA was found essential for root induction which is also seen in Fraser Firand Virginia pine tree (Saravitz et al. 1990, 1991) and in citrus lemon micropropagation (Tornero et al. 2009). NAA induced roots were unhealthy as compared to IBA. Even IAA was not effective in inducing roots. The varied effects of different types of auxin can be attributed to their regulation on organogenesis. It is not only by their concentration but also by changes in sensitivity of the cells to different compounds (Gasper et al. 2002).

Present study contributes to the first report for effective successful regeneration of $R$. xylocarpa. The efficient in vitro propagation method reported here can be commercially utilized for immediate conservation, improved multiplication and reforestation of R. xylocarpa.

\section{Acknowledgement}

The authors are thankful to The Madhya Pradesh Minor Forest Produce Federation, Bhopal for providing financial grants and Chief Conservator of Forest, Research and Extension Circle, Indore (M.P.) for providing laboratory infrastructure to carry out this work successfully. They would like to thank the forest officials for assisting during the field trials.

\section{References}

Anna P Caniato, R Cappelleti EM and Filippini R (2010) Organogenesis from shoot segments and via callus of endangered Kosteletzkyapentacarpos (L.) Ledeb. Plant Cell Tiss. Org. Cult. 100: 309-315. doi: 10.1007/s11240-009-9652-5 
Bonga JM (1987) Clonal propagation of mature trees, problems and possible solutions. In: Bonga JM and Durzan DJ (ed.) Cell and Tissue culture. Martinus Nijhoft Publishers Dordrecht. pp. 249-271.

Bonga JM, Klimaszewska KK and Von Aderkas P (2010) Recalcitrance in clonal propagation, in particular of conifers. Plant Cell Tiss. Org. Cult. 100: 241-254 Doi: 10.1007/s11240-009-9647-2

David Paul Raj RS, Morais SM and Gopalakrishnan K (2010) In vitro propagation and cell suspension culture of Callistemon citrinus L. Indian J. Sci. Techol. 3(1): 67-69.

Desai HK, Gawad DG, Joshi Parthsarathy PC, Ravindranath KR, Saindane MT, Sidhaye AR and Viswanathan N (1977) Chemical investigation of Indian plants: Part X. Ind. J. Chem. 15B: 291.

Drew RA (1988) Rapid clonal propagation of papaya in vitro from mature field grown trees. Hort Sci. 23: 609-611.

Gasper TH and Coumnas M (1987) Root formation. In: Bonga JM, and Durzan DJ (ed.) Cell and Tissue Cult. Martinus Nijhoft Publishers Dordrecht. pp. 387-412.

Gasper T, Hausman JF, Faivre-Rampant O, Kevers C and Dommes J (2002) Auxins in the Biology of Roots. In: Waisel Y, Eshel A, Kafkafi L (ed.) Plant roots: The hidden half, 3rd edn. NY, Dekker. pp. 383-404.

Joshi BS, Gawad DH, William Pelletier S, Kartha G and Bhandary K (1984) The structure of radermachol, an unusual pigment from Raderma xylocarpa K. Schum. Tetrahedron Letters 25(51): 5847-5850 Doi-10.1016/S0040-4039(01)81701-9.

Luis PBC, Adriane CMGM, Silvica BRCC and Ana Christina MB (1999) Plant regeneration from seedling explants of Eucalyptus grandis - E. urophylla. Plant Cell Tiss. Org. Cult. 56: 17-23 DOI: 10.1023/A:1006283816625

Misra RC (2004) Therapeutic uses of some seeds among the trebles of Gandhmardan hill range. Indian J. Traditional Knowledge 3(1): 105-115.

Perez-Tornero O and Burgos L (2000) Different media requirements for micropropagation of apricot cultivars. Plant Cell Tiss. Org. Cult. 63: 133-141 Doi -10.1023/A: 1006430718024.

Perez-Tornero O, Tallon C and Porras I (2009) Citrus lemon micropropagation: Efficet of different phytohormones on multiplication and rooting. Acta Hort. 839: 57-62.

Prakash E, Shavalli Khan PS, Sairam RP and Rao KK (1999) Regeneration of plants from seed derived callus of Hybanthusenneaspermus L. Muell., a rare ethnobotanical herb. Plant Cell Rep. 18: 873-878 Doi -10.1007/s002990050677

Sairam RP; Rodrigues R and Rajasekharan R (2001) Shoot organogenesis and mass propagation of Coleus forkohlii from leaf-derived callus. Plant Cell Tiss. Org. Cult. 66: 183-188 Doi-10.1023/A:1010697813852

Saravitz Carole H, Blazich Frank A and Amerson Henry V (1990) In vitro rooting of hypocotyl cuttings of Fraser Fir. Horticultural Science 25(12): 1650-1651. 
Saravitz CH, Blazich FA and Amerson HV (1991) In vitro propagation of virginia pine from cotyledons. J. Amer. Soc. Hort. Sci. 116(2): 362-365.

Shetgiri NP, Kokitkar SV and Sawant SN (2001) Radermachera xylocarpa: The highly efficient source of lapachol and synthesis of its derivatives. Acta Poloniae Pharmaceutica 58(2): 133-135.

Singh EA, Kamble SY, Bipinraj NK and Jagtap SD (2012) Medicinal plants used by the thakar tribes of Raigad district, Maharashtra for the treatment of snake-bite and scorpion- bite. International J. Phytothearpy Research 2(2): 26-35.

Surendran C, Parthiban KT, Vanangamudi K and Balaji S (2000) Vegetative propagation of trees, principles and practices. Coimbatore, India.

Wldi E, Schaffner W and Berger KB (1998) In vitro propagation of Petasiteshybridus (Asteraceae) from leaf and petiole explants and from inflorescence buds. Plant Cell Rep. 18: 336-340 Doi-10.1007/s002990050582

Yemets AI, Klimkina LAA, Tarassenko LV and Blume YB (2003) Efficient callus formation and plant regeneration of goosegrass (Eleusine indica). Plant Cell Rep. 21: 503-510 Doi -10.1007/s00299-002-0549-6

Zaer JB and Mapes MO (1982) Action of growth regulators. In: Bonga JM and Durzan DJ (ed.) Plant Cell Tiss. Cult. Martinus-Nijhof Dordrechet. Boston, Lancanster. pp. 231255. 